\title{
ISOTOPE RECORDS FROM MONGOLIAN AND ALPINE ICE CORES AS CLIMATE INDICATORS
}

\author{
U. SCHOTTERER \\ Department of Climate and Environmental Physics, University of Bern, Sidlerstrasse 5, CH 3012 \\ Bern and Paul Scherrer Institute, CH-5232 Villigen, Switzerland \\ K. FRÖHLICH \\ Isotope Hydrology Section, International Atomic Energy Agency, P.O. Box 100, A-1400 Vienna, \\ Austria \\ H. W. GÄGGELER \\ Institute of Radio- and Environmental Chemistry, University of Bern, Freiestrasse 12, \\ CH 3012 Bern and Paul Scherrer Institute, CH-5232 Villigen, Switzerland \\ S. SANDJORDJ \\ Institute for Water Problems, Ulan Baator, Mongolia \\ W. STICHLER \\ GSF - Institute for Hydrology, Neuherberg, 85758 Oberschleissheim, Germany
}

\begin{abstract}
The link between long term changes in the isotopic composition of precipitation and surface air temperature at a given location is of exceptional importance for paleoclimatic studies, as ahs been demonstrated by many recent publications based on the isotope records from polar ice cores. By means of direct comparison with instrumental data, this paper evaluates the potential of the deuterium and oxygen-18 records from two continental glaciers for monitoring climatic trends. The isotopic data presented characterize climatically contrasted enviroments. The records from the Swiss glacier show distinct seasonal variations. Oxygen-18 is fairly well correlated with the instrumental record of atmospheric temperature; the seasonal differences in deuterium excess reflect nearness to the oceanic moisture source. By contrast, the isotope data from the Mongolian site show poor correlation with atmospheric temperature. The seasonal variations in deuterium excess, with higher values during summer time, indicate that precipitation largely originates from re-evaporated continental moisture sources. In both cases however, the correlation with temperature is significantly improved by the elimination of values derived from years where major changes in seasonal distribution and/or snow loss obviously have occurred, thereby distoring the isotopic ratios for that particular year. Depending on the site selected for study, the stable isotope composition of ice cores should therefore be viewed not only as a proxy for atmospheric temperature, but also as an additional hydrometeorological parameter and source indicator for atmospheric moisture.
\end{abstract}

\section{Introduction}

Ice cores often contain the most direct proxy information available concerning past changes in climate and environment. Cold glaciers and ice sheets preserve sequential information on both wet and dry deposition. Dust content provides information on aridity and storminess, occluded air bubbles about greenhouse gases, chemical tracers about processes on land, in the ocean and in the atmosphere. Deuterium and oxygen-18 contain information about atmospheric temperature and the behaviour of the water cycle. Their variability in the snow flakes forming in

Climatic Change 36: 519-530, 1997.

(C) 1997 Kluwer Academic Publishers. Printed in the Netherlands. 
the atmosphere is controlled by numerous meteorological factors. The deuterium excess, for example, is mainly related to temperature and humidity in the moisture source area (Dansgaard, 1964; Merlivat and Jouzel, 1979; Johnsen et al., 1989). In particular, the results obtained from deep ice cores in Greenland and Antarctica have confirmed the potential of these natural archives for reconstructing past climates, nevertheless the isotope/temperature relation still remains controversial. (GRIP Members, 1993; Jouzel et al., 1993; Alley et al., 1993; Charles et al., 1995).

Cold, high, alpine glaciers or ice caps located in mid- and low latitudes have been explored as climatic and environmental archives in much the same way as the large polar ice caps. Under favourable conditions they provide detailed proxy information on hydroclimatic changes which additionally may be related either to contemporary instrumental records or to other nearby proxy archives. This is important for establishing a more objectively validated and quantitative reconstruction of long-term fluctuations in key climatic parameters like atmospheric temperature, precipitation amount, or relative humidity in the area studied.

During the last two decades, several ice cores have been drilled to bedrock at such sites (Schotterer et al., 1985; Thompson et al., 1989, 1995). Unfortunately the interpretation of the data obtained is often more difficult than in the case of polar ice caps. At altitudes between 4000 and $6500 \mathrm{~m}$, the sampling sites are often influenced by conditions in the mid to higher troposphere. Other restrictions may arise from wind erosion or post depositional alteration of chemical signals due to meltwater percolation. Reduced ice thickness in summit regions often limits the time resolution of the individual records.

\section{Drilling Sites}

Both the Swiss glacier and the Mongolian ice cap are situated at $4000 \mathrm{~m}$ altitude (Figure 1). One advantage of European glaciers as climatic and environmental archives is the availability of high quality instrumental records; moreover, sources of anthropogenic emissions are near and also relatively well known (Wagenbach et al., 1988; Maupetit et al., 1995; Döscher et al., 1996). These advantages allow more detailed investigations of the transfer processes and the deposition rates of various physical and chemical constituents (Haeberli et al., 1983). They also make it possible to compare the ice core data with direct measurements in order to extend the latter more quantitatively over longer time scales. There are also several stations located in the Swiss Alps which have provided records of isotopes in precipitation since 1971.

The ice cores on the Fiescherhorn plateau in the Bernese Alps were drilled between 1986 and 1989. The deepest core reached a depth of $77 \mathrm{~m}$, close to bedrock at c. $85 \mathrm{~m}$. Though it may be deduced from the presence of ice lenses that summer melting occurs, the borehole temperature at $8 \mathrm{~m}$ depth has already fallen to $-6.5^{\circ} \mathrm{C}$ (Schweitzer and Schmid, VAW-ETHZ, unpublished data). The site was 


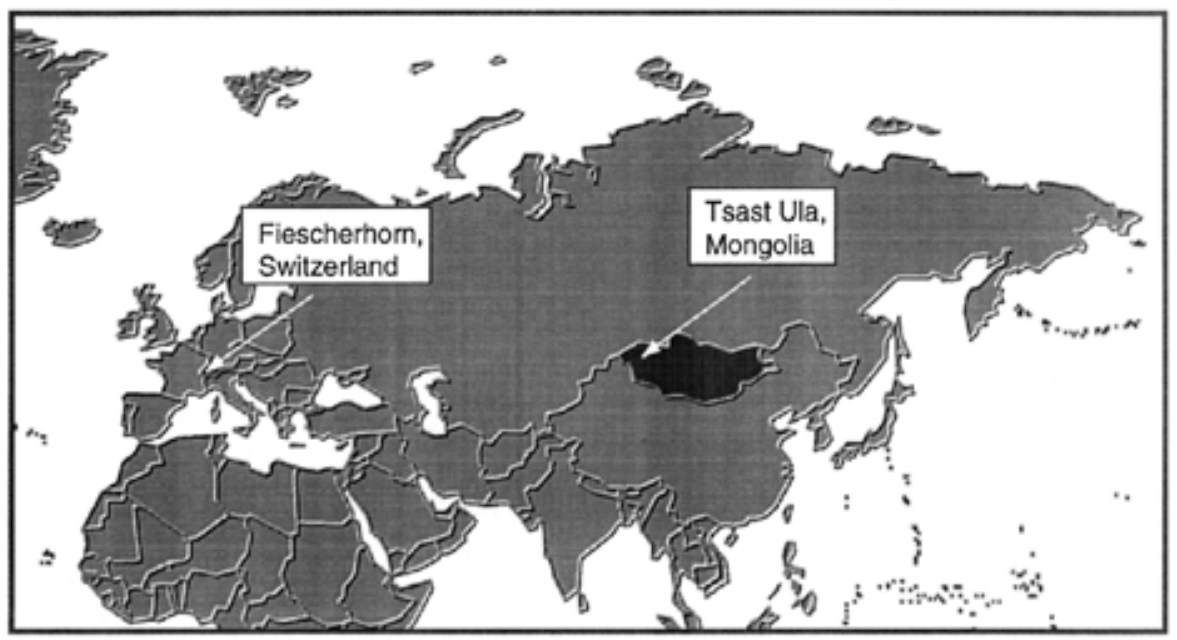

Figure 1. Both the Swiss glacier (Fiescherhorn) and the Mongolian ice cap (Tsast Ula) are situated at $4000 \mathrm{~m}$ altitude. The two drilling sites are characterized by differences in their distance from the ocean and in the influence of re-evaporated continental moisture.

chosen in the expectation of higher accumulation rates than those prevailing on other cold summit glaciers in the Swiss alps; also because of the opportunity to link the ice core data to various instrumental records from the nearby research station Jungfraujoch at $3500 \mathrm{~m}$ altitude. The initial purpose for drilling was the reconstruction of Chernobyl fallout in May 1986 (Gäggeler et al., 1986).

Mongolia is perhaps the most strongly continental country in the world. Precipitation is highly variable, most of it occurring during summer time, with average values no greater than $150 \mathrm{~mm}$ per year. The glaciated area covers approximately $500 \mathrm{~km}^{2}$ and comprises small glaciers and ice caps in Western Mongolia. Temperatures in January may quite often fall below $-40^{\circ} \mathrm{C}$, whilst the summer is short and hot. Through an IAEA supported water development programme, isotope methods were applied to estimate recharge conditions and residence times for groundwater conservation in the region. Since no time series of input data existed to which the isotope concentrations of groundwater could be related, shallow ice cores were drilled to obtain the necessary data.

The cores at the summit of the Tast Ula ice cap drilled in June 1991, reached a depth of $10 \mathrm{~m}$. Borehole temperatures showed stable values of about $-18{ }^{\circ} \mathrm{C}$ from $5 \mathrm{~m}$ down. Only a very few, thin ice lenses were observed. Meteorological data for the last 30 years were obtained from the station Chowd (1500 m altitude) at a distance of about $100 \mathrm{~km}$. The isotope records are presented for the first time; a detailed compilation of all data will be published elsewhere. 


\section{Interpretation of the Isotope Records}

To assess the potential of the stable isotope composition of meteoric water as a proxy indicator of climate, its relation to surface air temperature, amount of precipitation, and transport of water vapour in the lower atmosphere should be investigated. The available data on the isotopic composition of precipitation gathered over the last three decades, mainly through the IAEA/WMO Global Network for Isotopes in Precipitation (GNIP), suggest that, at a first approximation, temperature controls the isotopic composition of precipitation over high and mid latitudes, whereas the amount of precipitation is a dominating factor in tropical regions. Atmospheric circulation patterns, linking the vapour source regions with precipitation sites, are of importance in both cases (Yurtsever and Gat, 1981; Rozanski et al., 1993).

Figure 2 compares the oxygen-18 and deuterium records from both drilling sites. Due to the high temporal resolution of the sampling (c. 14 data points per year) a 7-point moving average was applied to the Fischerhorn data in order to highlight the effects of seasonality. The Tsast Ula record is less closely resolved; moreover, the incidence of precipitation events in Mongolia is much more irregular, therefore all individual isotope values are shown. The data are plotted against depth in $\mathrm{cm}$ of water equivalent, and against time. Dates were obtained by counting seasonal isotope and conductivity layers, and confirmed by tritium measurements. The main tritium peaks from nuclear weapon testing and industrial tritium release as recorded in the GNIP data base were used for this purpose. In the case of Tsast Ula tritium peaks recorded in 1972 and 1974/75 confirmed the time interval derived from annual layer counting (see also Figure 3). The total length of the Fiescherhorn ice core covers four decades, from which the last 20 years are compared with the equivalent time slice covered by the Mongolian ice core.

\subsection{VAPOUR SOURCE AND ATMOSPHERIC CIRCULATION}

To link dominant vapour source regions to the precipitation site, the deuterium excess can be used. The concept of the deuterium excess $(d)$ is defined as $d=$ $\delta \mathrm{D}-8 \delta^{18} \mathrm{O}$. In addition to phase changes under equilibrium conditions, the higher diffusity for ${ }^{1} \mathrm{H}^{2} \mathrm{H}^{16} \mathrm{O}$ as related to ${ }^{1} \mathrm{H}^{1} \mathrm{H}^{18} \mathrm{O}$ results in an additional isotopic separation; $d$ increases with decreasing humidity of oceanic air masses relative to the respective sea surface temperature (SST). A higher deuterium excess in precipitation can also arise from significant additions of re-evaporated moisture from continental basins to the water vapour travelling inland (Gat and Matsui, 1991).

The isotope records from the two glaciers under investigation are generated by quite different moisture sources, as is clearly expressed by the contrast in their oxygen-18/deuterium excess relationship. The shaded areas in Figure 2 highlight this contrast in some well preserved annual layers. The European glacier stores an isotope record with seasonal variations typical of precipitation in mid and high 


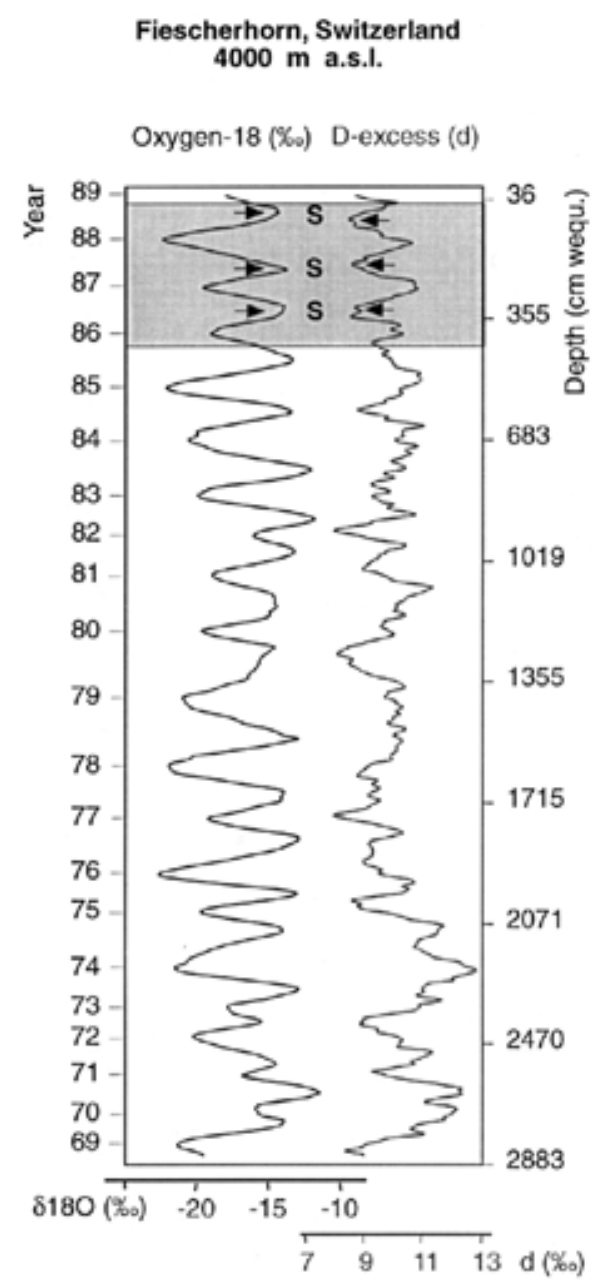

Tsast Ula, Mongolia

$4000 \mathrm{~m}$ a.s.l.

Oxygen-18 D-excess (d)

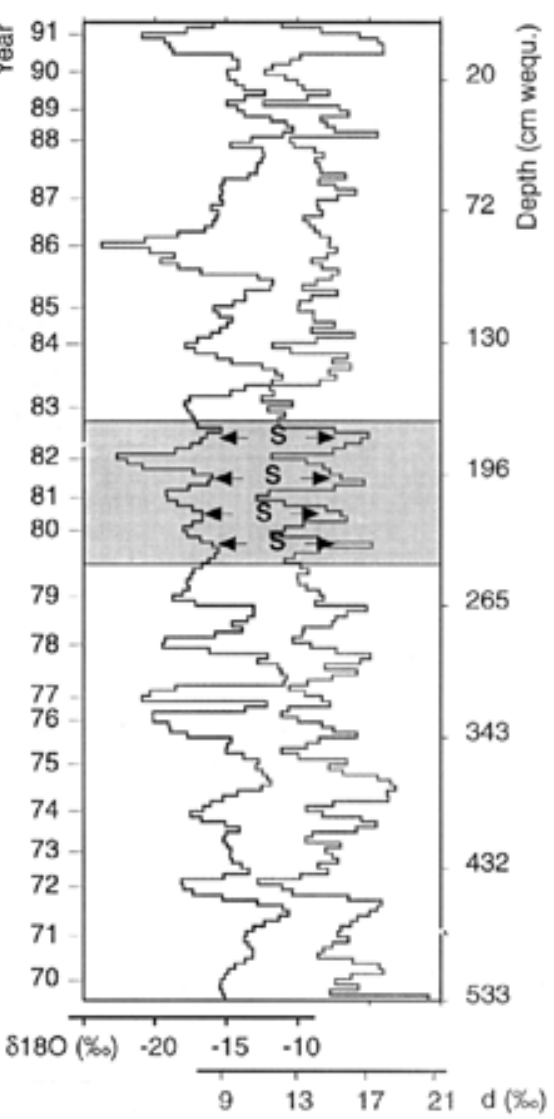

Figure 2. Oxygen-18 and deuterium excess $(d)$ from the Fischerhorn glacier and Tsast Ula ice cap plotted against depth in $\mathrm{cm}$ of water equivalent. Shaded areas indicate core sections where different relationships between the oxygen-18 and deuterium excess signatures can be clearly seen. Precipitation originating from re-evaporated moisture is enriched in deuterium relative to oxygen-18. The higher deuterium excess during summer in the Mongolian ice core points to the dominance of this continental moisture source.

latitudes where the oceanic moisture source dominates. The significantly higher $d$ values in winter (low oxygen-18) as compared with summer precipitation, are a reflection of relative humidity values that are lower when related to the SST prevailing at that time. The more irregular seasonality in the deuterium excess may be partly explained by occasional summer melting but also by fluctuations in the source region. From instrumental records and the Greenland ice core data, we know that a major part of the variability in European weather and climate is caused 


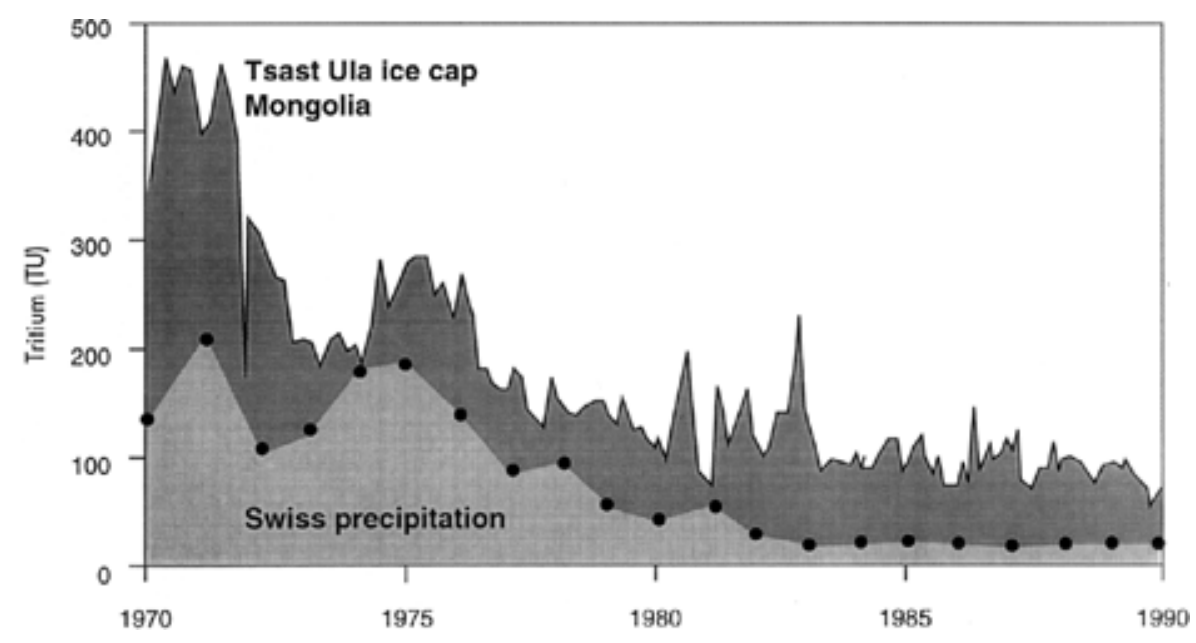

Figure 3. Comparison of yearly mean tritium concentrations in Swiss precipitation (Grimsel, $2000 \mathrm{~m}$ a.s.l.) and the tritium concentrations from the Tsast Ula ice cap. The generally higher concentrations from the latter can be explained by the dominant influence of moisture re-evaporated from parts of the Asian continent, which still releases considerable amounts of tritium from earlier nuclear weapons tests.

by the North Atlantic Oscillation, which is related to changes in SST and relative humidity (Barlow et al., 1993; Hurrell and van Loon, this issue).

The deuterium excess values in the Tsast Ula ice core generally show the opposite trend with higher $d$ values mainly accompanied with more enriched oxygen-18 values during the main precipitation events in summer. Monsoon derived precipitation during this time can be excluded. Its predominant amount effect would result in a distinct depletion in $\delta^{18} \mathrm{O}$ and $\delta \mathrm{D}$ respectively which cannot be denoted from the ice core record. Additionally there is no indication in the GNIP data base that monsoon derived precipitation can be characterized by increased deuterium excess values. The seasonality ice core record is also more pronounced in $d$ than in oxygen-18. This points to a seasonal change in the moisture regime. As previously mentioned, higher deuterium excess in precipitation can also arise from significant additional of re-evaporated moisture. Summer precipitation in this region may therefore originate from continental sources, probably from Siberian lakes and swamps. The findings are supported also by the tritium record in Figure 3. Due to the long residence time of ocean water as compared to the half life of tritium the oceans act as a sink for atmospheric tritium. The tritium concentration in precipitation therefore increases generally with increasing distance from the coast (Schell et al., 1974). The higher tritium concentrations in the Tsast Ula ice core as compared to reference values for Swiss precipitation may be taken also as a sign of re-evaporated moisture from parts of the Asian continent, which obviously still releases considerable amounts of tritium from previous thermonuclear weapon tests. 
From 1985 onwards the stable isotope signal in the ice core becomes more irregular. Since the distribution of the few thin ice lenses does not show any significant change it may be excluded that enhanced post depositional summer melting disturbed the record. Changes in the seasonality of moisture origin and precipitation pattern may account for it, but this has to be proved on longer records which are not available yet.

\subsection{AMOUNT OF PRECIPITATION AND SEASONAL DISTRIBUTION}

The net accumulation of snow on summit glaciers is very often controlled by wind erosion, which is particularly intensive during winter time. For example the $\delta^{18} \mathrm{O}$ average (period 1910-1978) on the Colle Gnifetti glacier, located on the SwissItalian border (4500 $\mathrm{m}$ a.s.1.), is $-14.5 \%$ o, several points permil too high for this altitude. This points to preferential loss of winter precipitation, thus confirming the importance of erosion events. To establish a $\delta^{18} \mathrm{O} /$ temperature coefficient on a yearly base is therefore not possible in this instance (Rozanski et al., 1997). The $500 \mathrm{~m}$ lower Fiescherhorn plateau has an average $\delta^{18} \mathrm{O}$ value of $-17 \%$ or the period 1969 to 1989; the seasonal distribution of accumulated snow seems to be well preserved. This reflects control by the regional $\delta^{18} \mathrm{O} /$ altitude effect (Figure 4). When air masses are orographically uplifted, they cool and precipitate preferentially the heavier isotopes. Based on data from the Swiss network for isotopes in precipitation (Schotterer et al., 1995), this effect is $0.2 \%$ o for each $100 \mathrm{~m}$ of altitude gained. This estimate has been calculated for the period 1983 to 1988 from monthly isotopes-in-precipitation data and from the mean ice core data for the same time interval. The $\delta^{18} \mathrm{O} /$ altitude effect is extremely sensitive to any disturbance or loss (for example by possible wind erosion in the case of the Fiescherhorn) on a seasonal basis. Since the mean difference between winter and summer precipitation is in the order of 6 to $8 \% \circ$ in $\delta^{18} \mathrm{O}$, any loss of winter precipitation would result in an apparent 'drop in altitude' and an offset from the linear $\delta^{18} \mathrm{O} /$ altitude relationship. According to Figure 4 this is not the case. Clearly, well preserved seasonal variations in the isotope ratios in snow layers may therefore be used to confirm the validity of calculations of total precipitation for high altitude sites based on measurements of past snow accumulation. For the Fiescherhorn this results in a yearly mean value $1.5 \mathrm{~m}$ of water equivalent (varying between one and two meters).

For the Mongolian site, this type of detailed calculation is not possible. We can only compare the mean net accumulation with the precipitation data from the station Chowd at $1500 \mathrm{~m}$ altitude for the time covered by the ice core. The yearly mean precipitation is $0.12 \mathrm{~m}$ and varies between 0.06 and $0.21 \mathrm{~m}$. Summer precipitation dominates with up to $80 \%$ of the annual total. The yearly mean accumulation rate, as derived from the ice core data, is $0.25 \mathrm{~m}$ of water equivalent which is an indication of increasing precipitation with altitude. From the seasonal shift and the 


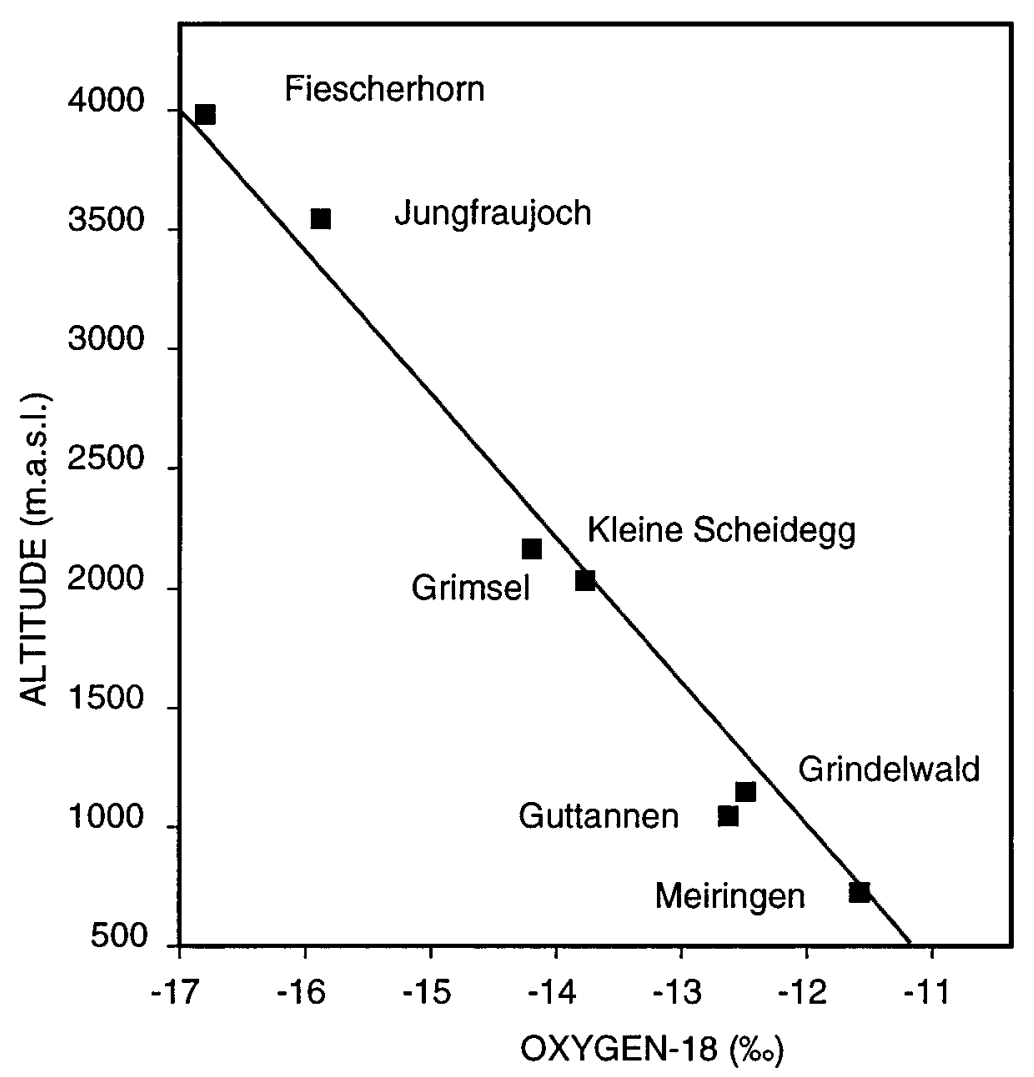

Figure 4. Average oxygen-18/altitude relation for the period 1983 to 1988. The Fiescherhorn data match the linear relationship derived from the precipitation samples, indicating that the seasonal distribution of accumulated snow is not significantly disturbed at $4000 \mathrm{~m}$. In such cases the seasonal variations in the isotope signal can be used for precipitation measurements at high altitudes.

relation of high to low values in deuterium excess, it also may be concluded that at least a part of the winter precipitation is preserved.

\subsection{RELATION TO SURFACE AIR TEMPERATURE}

The long-term $\delta^{18} \mathrm{O} /$ temperature coefficient in precipitation for yearly means in mid and high latitudes as derived from the IAEA/WMO Global Network for Isotopes in Precipitation (GNIP) varies from 0.5 to $0.9 \%$ oper ${ }^{\circ} \mathrm{C}$. An average of $0.69 \%$ per ${ }^{\circ} \mathrm{C}$ has been used in numerous studies to reconstruct past temperatures. (Rozanski et al., 1993). It is only reasonable to establish a $\delta^{18} \mathrm{O} /$ temperature relationship with instrumental data if precipitation is regularly distributed throughout the year, or if the seasonal proportions have remained constant. For the Swiss stations the former is generally the case; the relation of winter to summer precipitation is approximately equal, the long term mean $\delta^{18} \mathrm{O} / \mathrm{T}$ gradient for winter being generally somewhat lower than for summer; but all averages, including the annual 
means of all stations, fit within the published range. In years with very regular precipitation distribution, a $\delta^{18} \mathrm{O} /$ temperature relationship can be established even on a monthly basis for the Fiescherhorn core. Moreover, the values are compatible with the long term means cited above. This is confirmed by the comparison between the monthly instrumental data from Jungfraujoch for $1983 / 84$ and $\delta^{18} \mathrm{O}$ values for equally spaced, contiguous slices from the Fiescherhorn ice core from the same time interval (Figure 5). On longer time scales natural variability in the seasonal distribution of precipitation will modify the $\delta^{18} \mathrm{O} /$ temperature relation, unless the mean annual atmospheric temperature values are transformed to accommodate a major change in the seasonality of precipitation. As long as instrumental data are compared with direct measurements of isotopes in precipitation, this adjustment can be made. In the case of ice core records, even if the seasonal signal is sequentially preserved, it is much more difficult, but nevertheless quite crucial for any successful calibration. The lower part of Figure 5 illustrates the way in which this problem makes it difficult to calibrate oxygen-18 against instrumental data. Only when years with strongly anomalous data points are excluded does the correlation become quite reasonable. A closer look at the $\delta^{18} \mathrm{O} /$ temperature relation for different time intervals, as derived from the Swiss network, confirms that such 'outliers' are common and may represent another prevailing precipitation regime with a different isotope/temperature slope. On a glacier, years with disturbed accumulation patterns additionally influence the relation between $\delta^{18} \mathrm{O}$ deposited in snow layers and mean annual temperatures. Both effects may contribute to the steeper gradient of the $\delta^{18} \mathrm{O} /$ temperature slope in the investigated ice cores.

Unfortunately the Fiescherhorn ice core does not cover the whole recent warming trend which is also characterized by disturbed seasonality in precipitation. Three consecutive winters without snow cover in the Alps (1988-1991) were exceptional even on a century time scale. The warming trend can be recognized in isotope records from precipitation, rivers and shallow groundwater (Schotterer et al., 1993). The average increase in $\delta^{18} \mathrm{O}$ during the last 10 years is in the order of $1 \%$ with strong year to year variations. However, isotope-in-precipitation data from this period do not correlate with atmospheric temperature on the basis of yearly means.

\section{Conclusions}

Depending on the site selection, isotope records from cold continental glaciers and ice sheets can be used as sensitive climate indicators. At least for the Fiescherhorn site a convincing $\delta^{18} \mathrm{O} /$ temperature relation could be established for major parts of the core sections. Nevertheless a straightforward interpretation in terms of atmospheric temperature may often be misleading as indicated by the steeper slope of the $\delta^{18} \mathrm{O}$ /temperature gradient at both sites.

$\delta^{18} \mathrm{O} /$ temperature relationships for ice cores calibrated to direct isotope-inprecipitation measurements and/or instrumental data are only reasonable when 
Fiescherhorn $1983-1984$
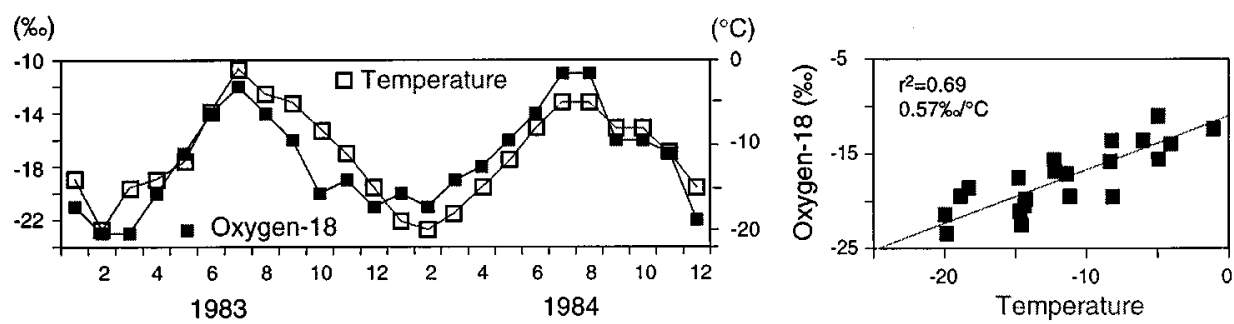

Jungfraujoch $1983-1984$

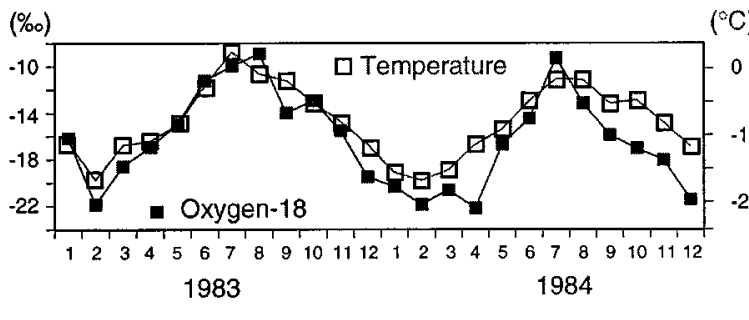

Fiescherhorn $1969-1989$

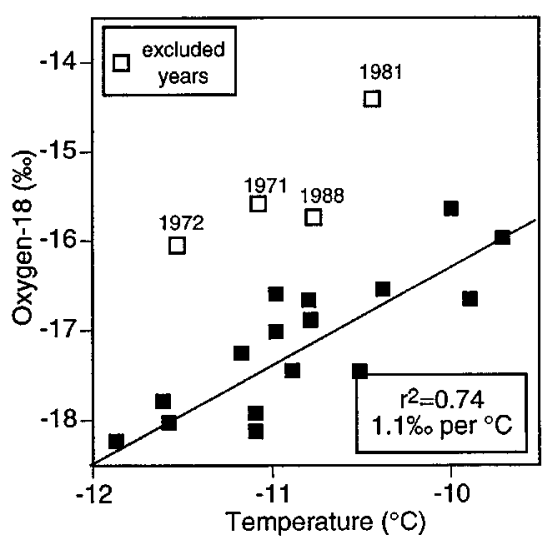

(C)

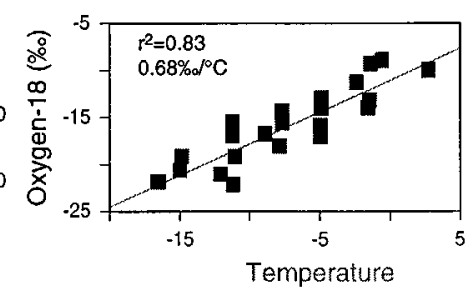

Tsast Ula $1970 \cdot 1991$

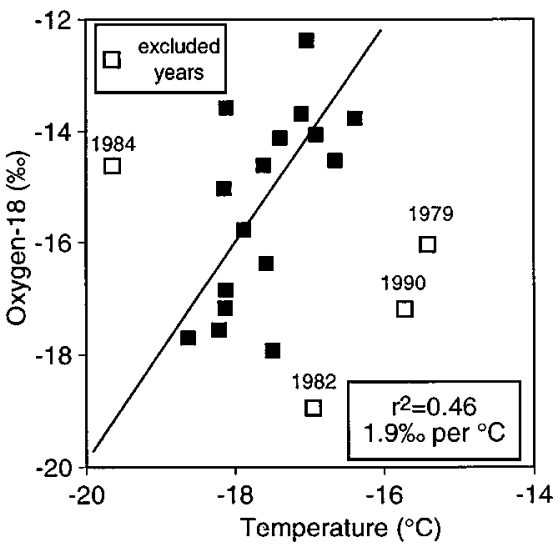

Figure 5. Oxygen-18/temperature relation for monthly composites of event based sampling (Jungfraujoch) and equally sliced ice core segments from Fiescherhorn for 1983/84 (upper part) and oxygen$18 /$ temperature relation as derived from the two sets of ice core data. The yearly means in oxygen-18 were derived by averaging seasonal layers, the atmospheric temperature by extrapolating nearby recorded instrumental data (Jungfraujoch, Switzerland, at $3600 \mathrm{~m}$ altitude and Chowd, Mongolia, at $1500 \mathrm{~m}$ altitude).

records with a similar seasonal distribution of precipitation are compared. Reconstructions based on stable isotope signatures may only be valid for a longer period back in time if precipitation was regularly distributed throughout the year, or if the seasonal proportions have remained constant. 
Changes within one source region of atmospheric moisture and/or between different source regions may contribute to different gradient for the $\delta^{18} \mathrm{O} /$ temperature slope, or even to a lack of correlation.

A lack of correlation or a strong variation in the stable isotope/temperature gradient does not invalidate the isotope approach to reconstruct past climates from ice cores. From the comparison with instrumental data, we have to learn that, instead of atmospheric temperature alone, stable isotopes in present and past precipitation represent also changes in source conditions, volume and seasonal distribution, continentality or a combination of all. At carefully selected continental glaciers, isotope records may therefore be viewed also as a tool to estimate more quantitatively changes in past hydrometeorological boundary conditions on a regional scale.

\section{Acknowledgements}

We wish to thank Frank Oldfield and Peter Trimborn for valuable comments which greatly improved this document. The intercalibrated measurements were performed at the isotope laboratories from IAEA in Vienna, the GSF-Institute for Hydrology in Neuherberg and the Institute of Climate and Environmental Physics in Bern. For the measurements in the latter Markus Leuenberger and Peter Nyfeler are acknowledged. Hansueli Buerki carefully performed the tritium measurements as well as sample and data management. The work was carried out within the IAEA technical cooperation project MON/8/002 and supported by the Swiss National Science Foundation, the Swiss Federal Office of Environment, Forests and Landscape and the helicopter services of the Swiss Army.

\section{References}

Alley, R. B., Meese, D. A., Shuman, C. A., Gow, A. J., Taylor, K. C., Grootes, P. M., White, J. W. C., Ram, M., Waddington, E. D., Mayewski, P. A., and Zielinski, G. A.: 1993, 'Abrupt Increase in Greenland Snow Accumulation at the End of the Younger Dryas Event', Nature 362, 527-529.

Barlow, L. K., White, J. W. C., Barry, R. C., Rogers, J. C., and Grootes, P. M.: 1993, 'The North Atlantic Oscillation Signature in Deuterium and Deuterium Excess Signals in the Greenland Ice Sheet Project 2 Ice Core, 1840-1970', Geophys. Res. Lett. 20, 2901-2904.

Charles, C. D., Rind, D., Jouzel, J., Kostner, and Fairbanks, R. G.: 1995, 'Seasonal Precipitation Timing and Ice Core Records', Science 269, 247-248.

Dansgaard, W.: 1964, 'Stable Isotopes in Precipitation', Tellus 16, 436-468.

Döscher, A., Gäggeler, H. W., Schotterer, U., and Schwikowski, K.: 1996, 'A 130 Year Record of Sulfate, Nitrate and Chloride from a High-Alpine Glacier', Water, Air and Soil Pollution 85, 603-609.

Gäggeler, H., Baltensberger, U., Jost, D., Schotterer, U., and Haeberli, W.: 1986, 'Depositionsmessungen von Spaltnukliden auf Schweizer Gletschern', in André, L., Boren, E. J., and Fischer, G. (eds.), Radioaktivitätsmessungen in der Schweiz nach Tschernobyl und ihre wissenschaftliche Interpretation, BAG, Berne, Switzerland, Band 1, pp. 238-248.

Gat, J. R. and Matsui, E.: 1991, 'Atmospheric Water Balance in the Amazon Basin: An Isotopic Evapotranspiration Model’, J. Geophys. Res. 96, 13179-13188. 
GRIP Project Members: 1993, 'Climate Instability during the Last Interglacial Period Recorded in the GRIP Ice Core', Nature 364, 203-208.

Haeberli, W., Schotterer, U., Wagenbach, D., Haeberli-Schwitter, H., and Bortenschlager, S.: 1983, 'Accumulation Characteristics on a Cold, High Alpine Firn Saddle from a Snow-Pit Study on Colle Gnifetti, Monte Rosa, Swiss Alps', J. Glaciol. 29, 260-271.

Hurrell, J. W. and van Loon, H.: 1997, 'Decadal Variations in Climate Associated with the North Atlantic Oscillation', Clim. Change (this issue).

Johnsen, S. J., Dansgaard, W., and White, J. W. C.: 1989, 'The Origin of Arctic Precipitation under Present and Glacial Conditions', Tellus 41B, 452-468.

Jouzel, J., Barkov, N. I., Barnola, J. M., Bender, M., Chappellaz, J., Genthon, C., Kotlyakov, V. M., Lipenkov, V., Lorius, C., Petit, J. R., Raynaud, D., Raisbeck, G., Ritz, C., Sowers, T., Stievenard, M., Yiou, F., and Yiou, P.: 1993, 'Extending the Vostok Ice-Core Record of Palaeoclimate to the Penultimate Glacial Period', Nature 364, 407-412.

Maupetit, F., Wagenbach, D., Weddeling, P., and Delmas, R. J.: 1995, 'Seasonal Fluxes of Major Ions to a High Altitude Cold Alpine Glacier', Atm. Env. 29, 1-9.

Merlivat, L. and Jouzel, J.: 1979, 'Global Climatic Interpretation of the Deuterium-Oxygen-18 Relationship for Precipitation', J. Geophys. Res. 84, 5029-5033.

Rozanski, K., Araguás, L., and Gonfiantini, R.: 1993, 'Isotopic Patterns in Modern Global Precipitation', in: Swart, P. K., Lohmann, K. C., McKenzie, J., and Savin, S. (eds.), Climate Change in Continental Isotopic Records, Geophysical Monograph 78, American Geophysical Union, pp. $1-37$.

Rozanski, K., Johnsen, S. J., Schotterer, U., and Thompson, L. G.: 1997, 'Reconstruction of Past Climates from Stable Isotope Records of Paleoprecipitation Preserved in Continental Archives', Hydrol. Sci. J. 42, in press.

Schell, W. R., Sauzay, G., and Payne, B. R.: 1974, 'World Distribution of Environmental Tritium', in Physical Behaviour of Radioactive Contaminants in the Atmosphere, IAEA Vienna, pp. 375-398.

Schotterer, U., Oeschger, H., Wagenbach, D., and Münnich, K. O.: 1985, 'Information on PaleoPrecipitation on a High-Altitude Glacier, Monte Rosa, Switzerland', Z. Gletscherkunde Glazialgeologie 21, 379-388.

Schotterer, U., Fröhllich, K., Stichler, W., and Trimborn, P.: 1993, 'Temporal Variations of Oxygen-18 and Deuterium Excess in Alpine Regions of Switzerland', in Isotope Techniques in the Study of Past and Current Environmental Changes in the Hydrosphere and the Atmosphere, International Atomic Energy Agency, Vienna, pp. 53-64.

Schotterer, U., Stocker, T., Hunziker, J., Buttet, P., and Tripet, J. P.: 1995, 'Isotope im Wasserkreislauf: Ein neues eidgenössisches Messnetz', Gas Wasser Abwasser 9 (Sonderdruck Nr. 1348), 2-8.

Thompson, L. G., Mosley-Thompson, E., Davis, M. E., Bolzan, J., Dai, J., Yao, T., Gundestrup, N., Wu, X., Klein, L., and Xie, Z.: 1989, 'Holocene-Late-Pleistocene Climatic Ice Core Records from Qinghai-Tibetan Plateau', Science 246, 474-477.

Thompson, L. G., Mosley-Thompson, E., Davis, M. E., Lin, P.-N., Henderson, K. A., Cole-Dai, J., Bolzan, J. F., and Liu, K. B.: 1995, 'Late Glacial Stage and Holocene Tropical Ice Core Records from Huascaran, Peru', Science 269, 46-50.

Wagenbach, D., Münnich, K. O., Schotterer, U., and Oeschger, H.: 1988, 'The Anthropogenic Impact on Snow Chemistry at Colle Gnifetti, Swiss Alps', Ann. Glaciol. 10, 183-187.

Yurtsever, Y. and Gat, J. R.: 1981, 'Atmospheric Waters', in: Gat, J. R. and Gonfiantini, R. (eds.), Stable Isotope Hydrology: Deuterium and Oxygen-18 in the Water Cycle, Technical Report Series No. 210, International Atomic Energy Agency, Vienna, Austria, pp. 103-142.

(Received 7 June 1996; in revised form 12 December 1996) 